International Journal of Engineering \& Technology, 7 (4.7) (2018) 463-467
International Journal of Engineering \& Technology
SPC
Website: www.sciencepubco.com/index.php/IJET
Research paper

\title{
Using Online Learning Systems to Measure Students’ Basic Teaching Skill
}

\author{
Enik Setiyawati*, Fitria Wulandari, Moch. Bahak Udin By Arifin, Hendra Erik Rudyanto, Ika Santia \\ ${ }^{1}$ Elementary School Teacher Education Department, Universitas Muhammadiyah Sidoarjo, Sidoarjo, Indonesia \\ ${ }^{2}$ Elementary School Teacher Education Department, Universitas Muhammadiyah Sidoarjo, Sidoarjo, Indonesia \\ ${ }^{3}$ Islamic Primary Teacher Education Department, Universitas Muhammadiyah Sidoarjo, Sidoarjo, Indonesia \\ ${ }^{4}$ Elementary School Teacher Education Department, Universitas PGRI Madiun, Madiun, Indonesia \\ ${ }^{5}$ Mathematics Education Department, Universitas Nusantara PGRI Kediri, Kediri, Indonesia \\ *Corresponding author E-mail: enik@umsida.ac.id
}

\begin{abstract}
The purpose of this article is to find out the achievement of the nine basic skills of teaching students through a scientific approach at the Department of Elementary Education Teacher Education (PGSD) of the Universitas Muhammadiyah Sidoarjo and to find out the constraints found during learning through the scientific approach in the PGSD of Universitas Muhammadiyah Sidoarjo. The purpose of this research is to improve the achievement of nine basic skills of teaching students through a scientific approach at the PGSD department of Muhammadiyah Sidoarjo University. This research was conducted using classroom action research (CAR) methods. In each PTK cycle, namely cycle 1, cycle 2, and cycle 3 there are several activities carried out, which are design, action and observation, reflection, and revision. Nine basic teaching skills for students have increased from cycle I to cycle II, and from cycle II to cycle III. This is indicated by the increasing skills of conducting variation, strengthening skills, and conducting evaluation skills.
\end{abstract}

Keywords: Online learning systems, teaching skills, seesaw class

\section{Introduction}

The Basic Teaching skills are skills that require decision making [1] and are complex [2]. These skills are applied by teachers in the teaching and learning process starting from the beginning to the end of teaching-learning process. Every basic teaching skill is the result of a decision, whether conscious or unconscious, that is made by the teacher after complex cognitive processing of available information. In addition, we know that not only the organizational conditions of the learning process but also the individual characteristics of the teacher influence their teaching skills [3]-[5].

All of these skills include: (1) skills in opening and closing lessons, (2) skills in explaining, (3) skills in asking questions, (4) skills in conducting variations, (5) skills in giving reinforcement, (6) skills in classroom management, (7) individual management skills, (8) small group teaching skills, and (9) skills in guiding small group discussions.

Students of elementary school teacher education study programs are prepared to become classroom teachers at the elementary school level, so starting from semester 5, they are trained to be able to master and practice the nine basic teaching skills in several courses. Based on the results of observations conducted by researchers in the 5th semester PGSD students, the following data was obtained:

Table 1: The Result of the Initial Observation on Basic Teaching Skills

\begin{tabular}{|c|c|c|}
\hline No. & Skill Type & Description \\
\hline 1 & $\begin{array}{l}\text { skills in opening and closing } \\
\text { lessons } \\
\text { skill in explaining }\end{array}$ & $\begin{array}{l}\text { Performed by praying, } \\
\text { attending, and singing } \\
\text { Performed by delivering }\end{array}$ \\
\hline
\end{tabular}

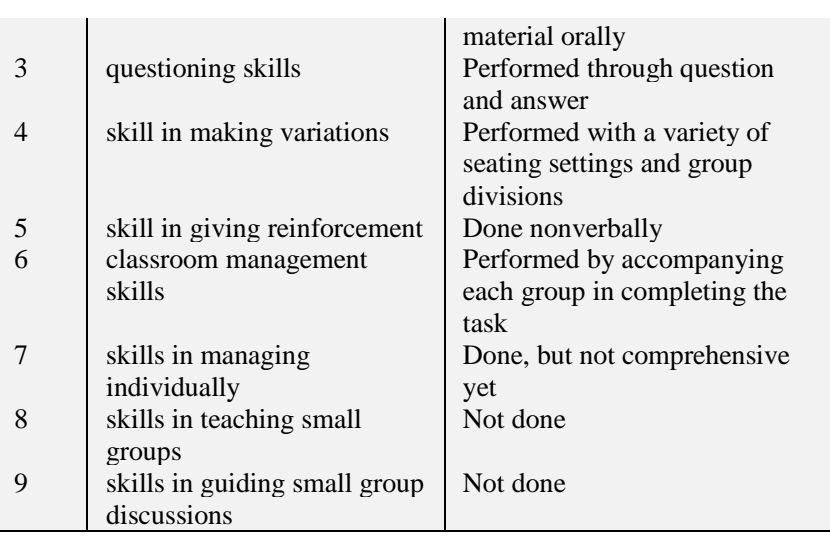

In order to optimize achievement nine basic teaching skills, one approach that can be used is a scientific approach. Learning that uses the scientific approach means learning by doing a reaseach (Team Assembly of Primary and Secondary Education (Dikdasmen) Executive Board of the Muhammadiyah Region (PWM) East Java, 2015). Research is an attempt to find the truth about something. Efforts in research in the form of research activities. In researching activities, scientific methods are needed. This method provides guidance for scientific thinking with systematic, methodical, objective measures, and applies to the public.

The stages in using a scientific approach are observing, asking questions, gathering information / exploration, associating / reasoning, and refining, and proceeding with creating. When the learning process reaches the stage of creation, the stage of communicating is repeated as a media to explain its creation. 
Information and Communication Technology (ICT) is a sophisticated tool that facilitates the teaching and learning process in the new digital era. Monterroso and Escutia show that higher education in the 21 st century cannot be understood without using such technology [6]. It is a challenge for teachers to implement educational innovations, use the benefits they offer to optimize learning, promote collaborative and cooperative learning, and develop new skills and cognitive skills for students who will face their professional future.

Online learning within the scope of tertiary education, encourages educators to face the learning assumptions that exist in tertiary education. Indeed, tertiary education leaders are challenged to position their institutions to meet the demands of prospective student connectivity and meet growing expectations and demands for more quality learning experiences and results [7] [8].

Most research in online teaching and learning has not focused on learning outcomes or academic achievement. Many of the works in this area focus on issues related to online teaching such as online teaching barriers, advantages and disadvantages of taking or teaching online classes, "how-to" descriptive articles, and social problems in online courses.

In the agreement, there is a demand for universities to "provide a cross section of larger and more diverse populations, to meet the emerging patterns of educational involvement that facilitate lifelong learning and to incorporate technology-based practices in the curriculum" [9]. Thus, this research was carried out with the aim of knowing how to use online learning systems through the Seesaw Class to measure the teaching basic skills of the students.

\section{Method}

Classroom Action Research (CAR) has been used in this research This is a form of reflective study by the perpetrator and is carried out to improve the teacher's ability to carry out the task, deepen the understanding of the actions taken and improve the conditions of learning practices that have been carried out (Sukidin, et al, 2002: 16)

Each cycle contains several activities, namely design, action and observation, reflection and revision. This study was conducted in the microteaching course in the PGSD department of Muhammadiyah University of Sidoarjo with a total of 29 students, through a scientific approach

The data obtained from the student teaching practice assessment sheet are then analyzed with the following formula:

$$
\mathrm{NA}(\text { teaching practice })=\frac{\text { score obtained }}{\max \text { imum score }}
$$

The final score (NA) obtained is then categorized with the following criteria: score $4=$ very good, score $3=$ good, score $2=$ good enough, and score $1=$ need guidance. This will then be described in the achievement of the nine basic teaching skills that have been practiced.

\section{Results and Discussions}

\section{Online Learning Systems through Seesaw Class}

Mobile learning can be part of the learning process [10]. The use of online learning systems through the seesaw class application has two display options, which are displays for the lecturer or teacher who operates and students or students who use. Each display has the functions and uses of each and there are almost the same.

Figure 1 shows the main view of seesaw through the smartphone application. This initial display determines our role in learning, namely as a teacher or student. To choose the teacher's role, the user must $\log$ in to the application using email. Meanwhile, students can enter without inputting an email just by inputting the class code created by the teacher.
Figure 2 shows the application display for the teacher or lecturer, where there are 5 facilities for using the application, they are journals that are used to write material about microteaching for students, useful activities as online worksheets that are used to provide student activities, inboxes to give notifications towards students or private messages such as giving revisions. Skills are useful as a scoresheet to find out the learning outcomes of students in each activity, and blogs are the same as journals, but blogs are accessed into a learning website so that it can be seen by the general public not only class members.

Figure 3 shows the layout to check whether students have provided responses or answered and carried out each activity. The responses given or inputted can be in the form of photos, videos, files, links, notes or drawings. Figure 4 shows a feed view that is useful to provide a review of the results of answers or student response results by providing revisions or suggestions needed. Lecturers and students can communicate through this.

Figure 5 shows that each student's response results, the lecturer provides feedback or value of teaching practices on a scale of 1-4, so that the overall student results can be checked or seen on the scoresheet or student skills. Scoresheet is only in the teacher's view, so other students cannot see the results of other students.

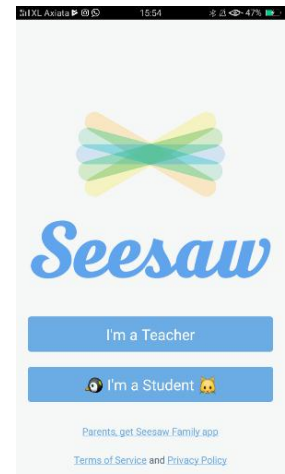

Figure 1. Initial Page Display of seesaw

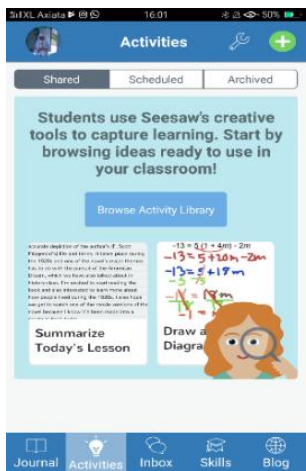

Figure 2. Teacher's/ Lecturer's Page display

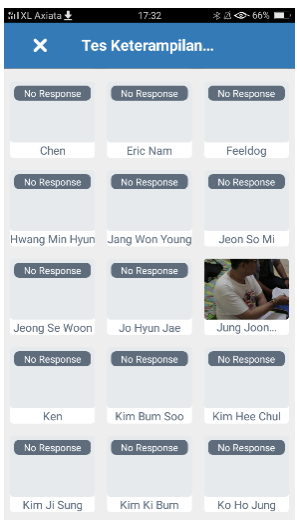

Figure 3. Result Page of Student Activity 

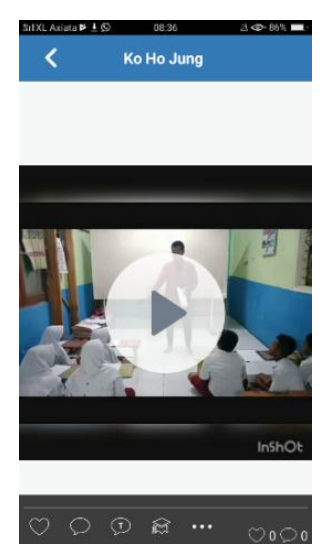

Figure 4: Feed view to give score and revise students assignments

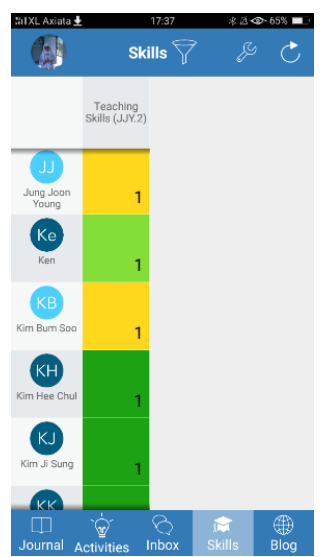

Figure 5: Student Score sheet

What follows is the use of seesaw from the perspective of students who use it. Displaying the use of seesaw class applications in students is explained in Figure 6 to Figure 9. Students can use mobile phones through applications or laptops through the website to use seesaw class.

In Figure 6 shows the display after students input the class code or scan the class QR Code. Figure 7 shows the activity pages to be carried out by students with several activities such as online worksheets. Figure 8 shows how students input or upload their answers or responses in several stages. Figure 9 shows the input of student data that is not automatic due to not entering email data when the application or website login.

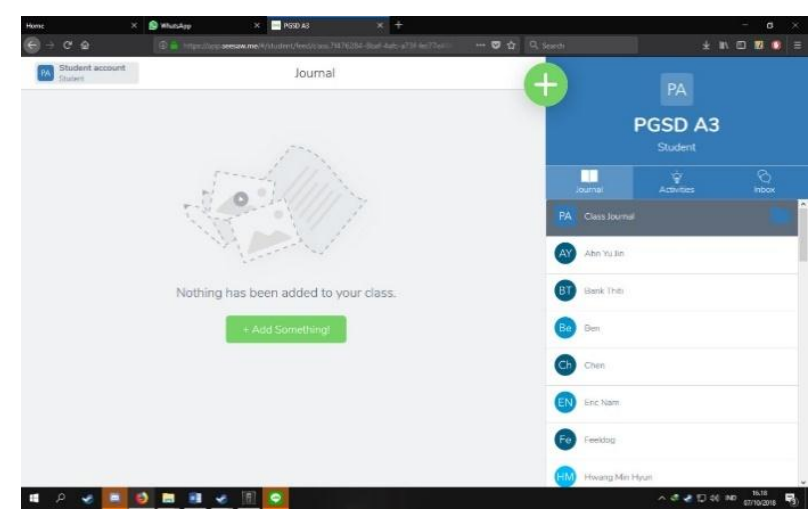

Figure 6: First layout for students

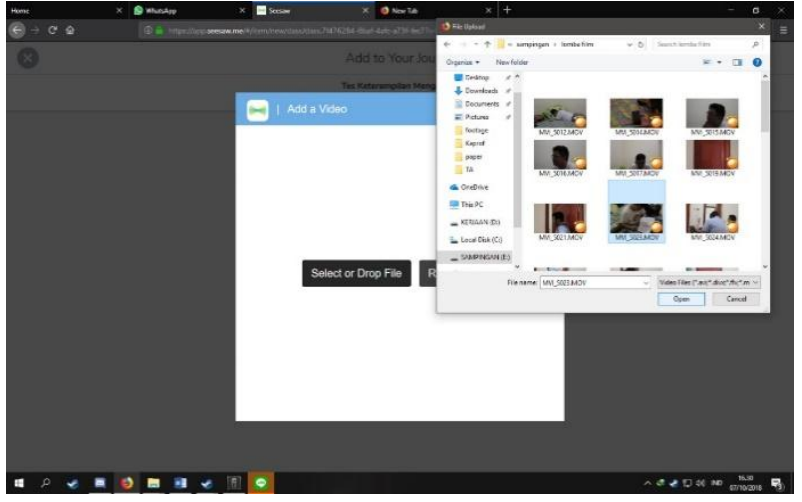

Figure 7. how to upload video's student

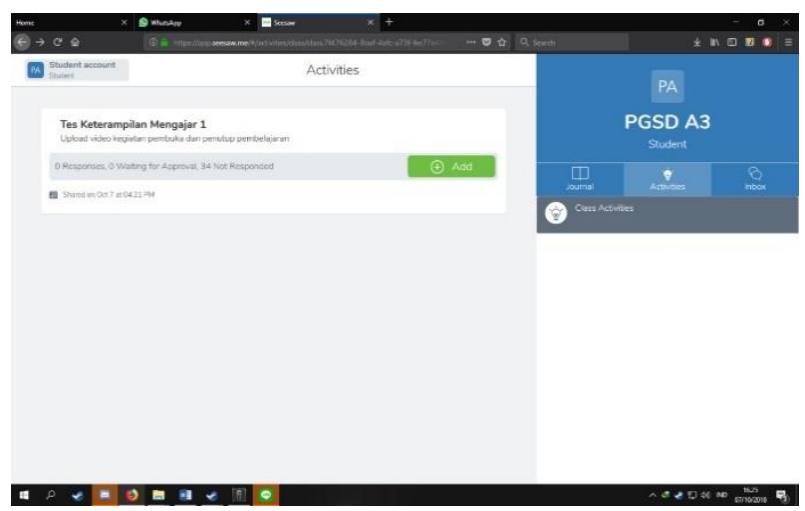

Figure 8. layout of class

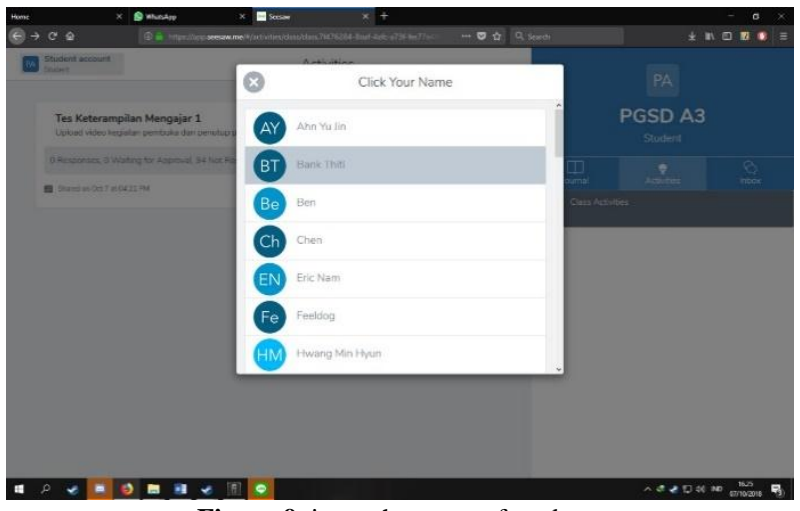

Figure 9. input the name of students

The use of online learning systems has made a considerable intuitive appeal for the concept of integrating the advantage of synchronous (face-to-face) learning and asynchronous learning activities (text-based Internet). At the same time, there is a considerable complexity in its implementation with the challenge of possibilities of application that are not limited to many contexts [11].

It is undeniable that campus-based higher education institutions will adopt an integrated learning approach in a significant way. As several institutions have shown, after a clear policy and strong leadership, evolution will be fast (eg, University of Central Florida). In just a few years, higher education institutions can be transformed in ways that are consistent with their values and reduce fiscal and pedagogical challenges and shortcomings that currently challenge the quality of classroom experience. Academic benefits, evidence and competitive advantages are clear; only the will and commitment are left. Online learning systems can begin the process needed to redefine higher education institutions as centralized learning and facilitate higher learning experiences.

Some might argue that the fact that there is a significant difference between midterm values is an indication that there is a difference between online classes and traditional classes in terms of learning. But as mentioned in the restriction section of this paper, this 
difference seems to be more of a problem of adjusting to online learning than being an indication that online classes are rather low in terms of learning outcomes [12].

The Result of Students' Basic Teaching Skills

The results obtained in this study are in the form of a full assessment of student teaching practices, which includes nine basic teaching skills per cycle.

Design

In the cycle I to III research design, the tools and equipment prepared include: Course Outline (RPS), Lesson Plan (RPP), assessment sheets for teaching practices, and, learning media needed during the activities.

Actions and Observations

The action taken by the researcher was in the form of teaching and learning activities of cycles I to III held on February 28, 2018. It began with an introduction, core activities, and then ended with a closing and 5 stages. On the scientific approach, what was done was lecturers giving motivation by conveying problems in learning that are often experienced by a teacher. Furthermore, students observe the symptoms of the cause of these problems. In the second activity, the lecturer divided the group and asked each group to discuss the nine basic teaching skills. The activities carried out are: students together with group members discuss in their group, then the class discussion for questions about various matters related to the nine basic teaching skills. Figure 10 is the result of the 3 cycles obtained during the study with a scale of $0-4$ which shows the increase in each cycle by students.

The discussion activity continued with Gathering Information by searching for information from various sources, namely books, journals, information from friends and learning videos. In addition, students also designed various teacher activities in learning to demonstrate the nine basic teaching skills. After designing learning activities, the students then prepare a report based on the results of the discussion. The report contains a series of activities conducted by the teacher to practice basic teaching skills in learning. After each group collects the report, then the student communicates in the form of teaching practice in the classroom individually to demonstrate the nine basic teaching skills.

\section{Reflection}

From the results of observations made in the first cycle, it can be seen that the shortcomings during the practice of teaching students is that most students still have difficulties in performing the skills of opening and closing lessons. Many students have not done all kinds of variations in learning. They also have not optimally provided small group guidance because of the difficulty in understanding the characteristics of students.

From the results of observations made in the second cycle, it can be seen that the shortcomings during the practice of teaching students is that only some students who have difficulty performing skills open the lesson to focus students' attention. Some students provide variations in learning only in the form of variations in teaching positions. Some students who are less than optimal provide small group guidance.

From the observations made in the third cycle, it can be seen that there are no significant weaknesses during the practice of teaching students, except for the problem of time control, which is still not able to be properly regulated by a small number of students.

Revision

This phase discusses improvements to be carried out in the second cycle after reflection on the implementation of teaching and learning activities in cycle I. These improvements are carried out to improve the achievement of nine basic teaching skills in the first cycle that have not reached the target or not maximized. The revision is done by the lecturer in giving additional time to students in carrying out "Observing" activities. Lecturers guide students as a whole in information gathering activities. Lecturers provide information related to media that should be used in demonstrating nine basic teaching skills, such as: miniature custom clothing, human respiratory organs, as well as twodimensional figure media. This makes students able to maximize their ideas in communicating the results of activities in reasoning. Revisions made in the second cycle are lecturers giving examples of demonstrating skills in opening lessons, so that students can observe the examples directly. Lecturers guide students individually in the activities of assisting learning tools in gathering information and reasoning.

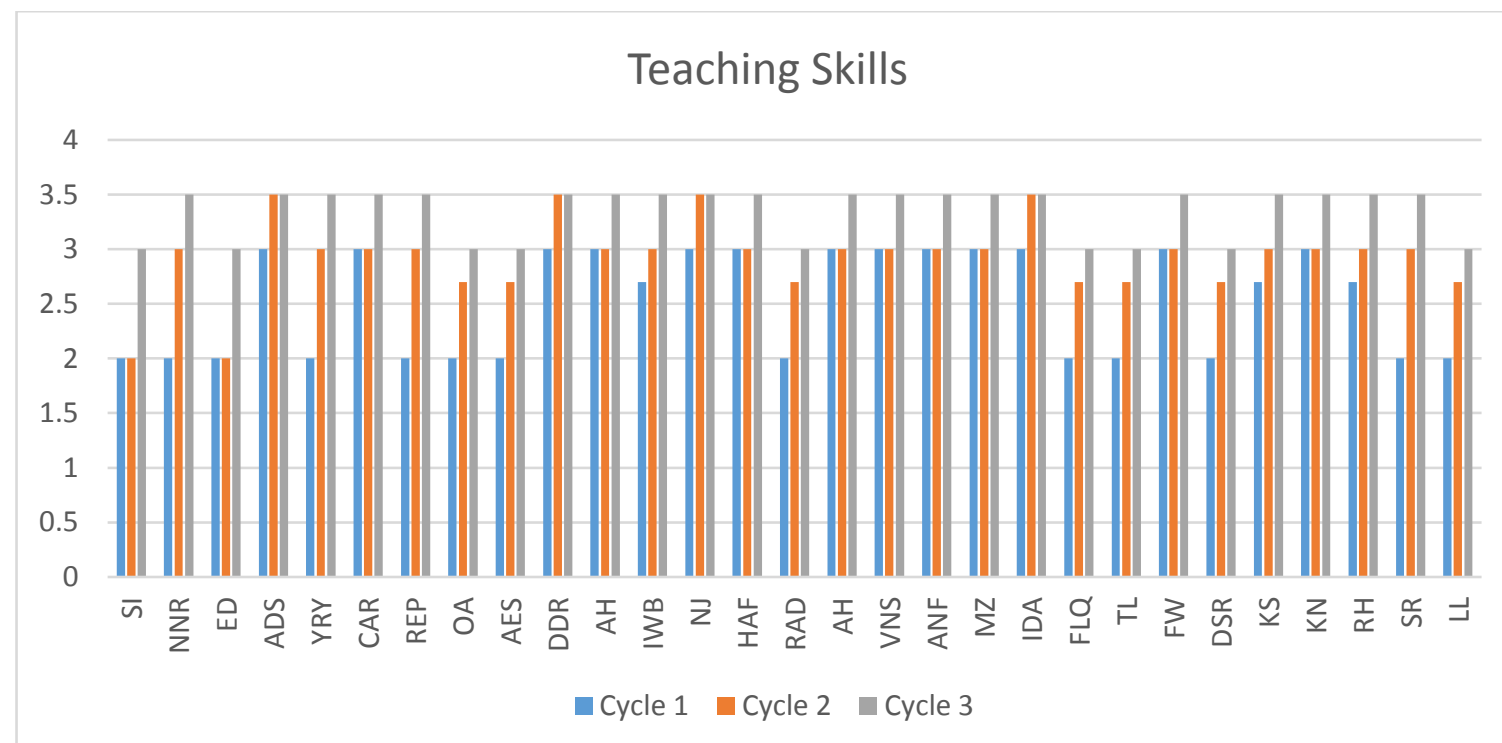

\section{Conclusion}

Based on the results and discussions, it can be concluded that the intact basic teaching skills consisting of nine skills have been achieved with good categories. In ICT-based learning can improve several aspects that support learning so that students or higher students improvement or ease in learning, as well as the use of augmented reality in learning to improve students spatial abilities [13][14].

\section{Acknowledgement}

We are thank you for Universitas Muhammadiyah Sidoarjo for funded this research publication. 


\section{References}

[1] R. J. Shavelson, "What Is The Basic Teaching Skill?," J. Teach. Educ., pp. 144-151, 1973.

[2] S. Shoffa, Keterampilan Dasar Mengajar. Jakarta: Mavendra Pers, 2017.

[3] M. Kunter, U. Klusmann, J. Baumert, D. Richter, T. Voss, and A Hachfeld, "Professional competence of teachers: Effect on instructional quality and student development," J. Educ. Psychol., vol. 105 , no. 3, pp. 805-820, 2013.

[4] J. E. Rockoff, B. A. Jacob, T. J. Kane, and D. O. Staiger, "Can you recognize an effective teacher when you recruit one?," Educ. Financ. Policy, vol. 6, no. 1, pp. 43-74, 2011.

[5] M. Cochran-Smith, S. Feiman-Nemser, and D. J. McIntyre Handbook of research on teacher education: Enduring question in changing contexts. New York: Manassas, 2008.

[6] E. Monterroso and R. Escutia, "Education Inmersiva: ensenanza practica del derecho en 3D," Rev. Comun. y Technol. emergentes, vol. 9, no. 2, pp. 83-100, 2014

[7] L. Shear and A. Lasseter, Understanding the Implications of Online Learning for Educational Productivity. Washington DC: Cebter for Technology in Learning SRI International, 2012.

[8] A. Biermann, J. Karbach, F. M. Spinath, and R. Brünken, "Investigating effects of the quality of fi eld experiences and personality on perceived teaching skills in German pre-service teachers for secondary schools," Teach. Teach. Educ., vol. 51, pp. 77-87, 2015.

[9] M. Hicks, I. Reid, and R. George, "Enhacing on-line teaching Designing responsive learning environment," Int. J. Acad. Dev., vol. 6 , no. 2 , pp. $143-151,2001$

[10] M. F. Amir, F. N. Hasanah, and H. Musthofa, "Interactive Multimedia Based Mathematics Problem Solving to Develop Student s ' Reasoning," Int. J. Eng. Technol., vol. 7, no. 2.14, pp. 272-276, 2018.

[11] D. R. Garrison and H. Kanuka, "Blended learning: Uncovering its transformative potential in higher education," Internet High. Educ., vol. 7, pp. 95-105, 2004

[12] L. Kirtman, "An Examination of Differences in Learning Outcomes Online Versus In-Class Courses :," Issues Teach. Educ., vol. 18, no. 2, pp. 103-116, 2009.

[13] M. F. Amir, N. Fediyanto, C. Chotimah, and H. E. Rudiyanto "Developing 3Dmetric Media Prototype through a Hypothetical Learning Trajector to Train Students Spatial Skill," J. Adv. Res Dyn. Control Syst., vol. 10, no. 02-Special Issue, pp. 1537-1542, 2018

[14] M. F. Amir, C. Chotimah, R. Afandi, H. E. Rudyanto, and I. Anshori, "Design Research Study: Investigation of Increasing Elementary Student' s Spatial Ability Using 3Dmetric," J. Adv. Res. Dyn. Control Syst., vol. 10, no. 6, pp. 1707-1713, 2018. 